\title{
Pembibitan Kentang Hitam (Solanum rotundifolius) dengan Pemberian PGPR Indigen
}

\author{
Germination of Black Potatoes (Solenostemon rotundifolius) by Giving PGPR Indigen \\ Ernata Dian Pratika ${ }^{1 *}$, Alfariza $^{1}$, Fathul Abib ${ }^{1}$, Sriwulan $^{1}$ \\ ${ }^{1}$ Program Studi Biologi, Universitas PGRI Ronggolawe, Tuban \\ *Email korespondensi: ernatadianp@gmail.com
}

Diterima: 15 Agustus 2019 / Disetujui: 20 Februari 2020

\begin{abstract}
Black potato (Solanum rotundifolius) is one of the horticultural plants that has the potential as an alternative food source. This is because this plant has a high carbohydrate content and various other important nutrient contents. The nurserry process of this plant by tubers, shoot cuttings, and tissue culture technology. However, the commonly done by farmers is using shoot cuttings. The cuttings of planted black potatoes are obtained from the potato tubers. The nursery process of potato tubers takes about one month. So need some efforts to accelerate this process, such as use PGPR. PGPR is a group of rhizosphere bacteria that has the potential as a biofertilizer, bio-stimulant, and bio-pretectant. This study aims to determine the nursery process of black potato tubers treated with PGPR. The procedure included the making of PGPR with doses of 0\%, 25\%, 50\%, $75 \%$, and $100 \%$, planting black potato bulbs which had been soaked with PGPR, and watering PGPR according to the doses in tubers planted. The process was observed by measuring shoot height, number of leaves, and number of buds. Observations carried out for 30 days. The results obtained showed that the administration of PGPR had an effect on the nursery process of black potato tubers based on the parameters of the shoot height and the number of leaves. Where, the 25\% dose gives the best result.
\end{abstract}

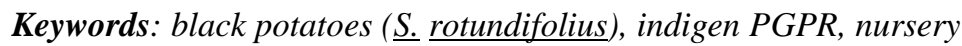

\begin{abstract}
ABSTRAK
Kentang hitam (Solanum rotundifolius) merupakan salah satu tanaman hortikultura yang berpotensi sebagai sumber pangan alternatif. Hal ini dikarenakan tanaman ini memiliki kandungan karbohidrat tinggi dan berbagai kandungan gizi penting lainnya. Upaya perbanyakan tanaman ini dapat dilakukan melalui umbi, stek pucuk, maupun teknologi kultur jaringan. Namun yang umum dilakukan oleh petani adalah dengan menggunakan stek pucuk. Stek pucuk tanaman kentang hitam yang ditanam diperoleh dari hasil pembibitan umbi kentang itu sendiri. Umumnya pembibitan umbi kentang membutuhkan waktu sekitar satu bulan. Waktu ini relatif cukup lama, sehingga dilakukan upaya untuk mempercepat proses pembibitan ini. Salah satu upaya yang dapat dilakukan adalah dengan menggunakan PGPR. PGPR merupakan kelompok bakteri rhizosfer yang memiliki potensi sebagai biofertilizer, biostimulan, dan biopretektan. Penelitian ini bertujuan untuk mengetahui proses pembibitan umbi kentang hitam yang diperlakukan dengan PGPR. Sedangkan prosedur dalam penelitian ini meliputi pembuatan bibit PGPR dan pengenceran PGPR dengan dosis 0\%, 25\%, 50\%, 75\%, dan 100\%, dan penanaman umbi kentang hitam yang telah direndam dengan PGPR sesuai perlakuan, dan dilakukan penyiraman PGPR sesuai doses pada umbi yang ditanam. Parameter yang diamati adalah tinggi tunas, jumlah daun, dan jumlah mata tunas. Pengamatan dilakukan selama 30 hari. Hasil yang diperoleh menunjukkan bahwa pemberian PGPR berpengaruh terhadap pembibitan umbi kentang hitam berdasarkan parameter tinggi tunas dan jumlah daun. Dimana, dosis $25 \%$ memberikan rerata pertumbuhan bibit kentang hitam yang paling baik.
\end{abstract}

Kata kunci: kentang hitam ( $\underline{\text { S. }}$ rotundifolius), pembibitan, PGPR indigen

\section{PENDAHULUAN}

Kentang hitam (Solanum rotundifolius) merupakan komoditas hortikultura penting di Indonesia yang saat ini dijadikan sebagai sumber bahan pangan alternatif karena mengandung karbohidrat yang tinggi. Selain itu, kentang hitam juga berkhasiat untuk penyembuhan penyakit maag, memiliki potensi sebagai antioksidan alami, dan antiproliferasi (anti perbanyakan sel kanker) golongan triterpenic acid (Nugraheni, et al., 2016). Ardani et al. (2017) menyebutkan bahwa umbi mentah kentang hitam per $100 \mathrm{~g}$ mengandung $76 \%$ air, $21 \%$ karbohidrat, $1,4 \%$ protein, $0,7 \%$ serat, $0,2 \%$ lemak serta $0,1 \%$ abu dan juga kaya vitamin dan mineral. Adanya berbagai kandungan ini menyebabkan tanaman kentang hitam menjadi salah satu bahan yang berpotensi dalam diversifikasi produk pangan. 
Budidaya kentang hitam dapat dilakukan dengan menggunakan umbi kentang, stek pucuk, dan hasil teknologi kultur jaringan. Namun, metode yang lebih banyak dilakukan oleh petani adalah dengan stek pucuk perkecambahan umbi kentang hitam. Stek pucuk yang digunakan umumnya merupakan stek pucuk yang diperoleh dari umbi kentang yang berukuran sekitar $10 \mathrm{~cm}$. Waktu yang dibutuhkan untuk mendapatkan stek pucuk ini sekitar satu bulan. Waktu ini relatif lama, sehingga diperlukan upaya untuk mempercepat tumbuhnya tunas. Salah satu bahan yang dapat dimanfaatkan untuk memacu pertumbuhan tunas pada umbi kentang hitam adalah PGPR.

PGPR merupakan kelompok rhizobacteria yang dapat berperan sebagai biostimulan tanaman. Bakteri-bakteri ini dapat membantu tanaman mendapatkan zat hara dengan lebih mudah. Dengan demikian pertmbuhan tanaman akan leih optimal. Kurniahu, et al. (2017) menyatakan bahwa penggunaan PGPR dapat membantu pmeningkatkan pertumbuhan tanaman jahe merah pada proses pembibitannya. Oleh karena itu pada penelitian ini penggunaan PGPR juga diharapkan dapat membantu mempercepat pertumbuhan tunas dari umbi kentang hitam, agar proses pembibitan kentang hitam dapat erlangsung lebih cepat.

\section{BAHAN DAN METODE}

\section{Alat dan Bahan}

Alat dan bahan yang digunakan dalam penelitian ini meliputi, umbi kentang hitam (Solanum rotundifolius), media tanam, polybag, air, tanah di sekitar perakaran tebu, bambu, alang-alang, jagung, dan rumput gajah, akuades, larutan buffer fosfat, timbangan, mortal dan pistil, cetok, pisau, gelas ukur, erlenmeter, botol plastik, penggaris, dan alat tulis.

\section{Prosedur}

Umbi kentang hitam dipilih dengan ukuran yang seragam. Umbi tersebut direndam dalam larutan PGPR dosis $0 \%, 25 \%, 50 \%, 75 \%$, dan $100 \%$. Umbi yang telah direndam ditanam pada media tanam yang telah disiapkan. Dilakukan penyiraman setiap hari dan diamati pertmbuhannya dengan para meter tinggi dan jumlah daun setiap satu minggu sekali selama 4 minggu.

\section{HASIL DAN PEMBAHASAN}

Hasil yang diperoleh pada penelitian ini berupa data tinggi dan jumlah daun tanaman kentang hitam dari umbi kentang yang ditanam. Hasil tersebut ditunjukan pada Gambar 1 dan Gambar 2 berikut. Pada Gambar 1 dan 2 dapat dilihat bahwa pemberian PGPR berpengaruh terhadap pertumbuhan tanaman kentang hitam pada proses pembibitan. Berdasarkan hasil analisis statistik diketahui bahwa dosis $25 \%, 50 \%$, 75\%, dan $100 \%$ memberikan respon pertumbuhan yang lebih baik bila dibandingakan dengan dosis $0 \%$.

Hasil tersebut menunjukkan bahwa PGPR dapat memacu pertumbuhan tanaman kentang hitam bila dibandingkan dengan dosis $0 \%$. PGPR dapat memacu pertumbuhan tanaman karena diduga memiliki potensi sebagai biofertilizer, biostimulan, dan bioprotektan.

Bakteri PGPR dapat membantu menyediakan zat hara bagi tanaman, salah satunya karena bakteri PGPR dapat membantu menambat nitrogen bebas di udara, sehingga dapat dimanfaatkan oleh tumbuhan. Nitrogen sendiri merupakan unsur hara esensial yang dibutuhkan tumbuhakan untuk membentuk asam amino, protein, dan asam nukleat.

Selain membantu menambat nitrogen, bakteri PGPR juga dapat membantu melarutkan fosfat. Fosfat dalam tanah, sebagian besar tersedia dalam bentuk terikat unsur logam. Adanya bakteri PGPR dapat membantu untuk memisahkan ikatan antara fosfat dengan logam tersebut, sehingga menjadi tersedia bagi tanaman. Unsup $\mathrm{P}$ juga merupakan unsur penting yang dibutuhkan tumbuhan. Ketersediaan zat hara ini akan membantu mengoptimalkan pertumbuhan tanaman.

Selain membantu ketersediaan hara bagi tanaman, PGPR juga menghasilkan fitohormon, seperti auksin dan sitokinin. Auksin dan sitokinin merupakan hormon pemacu tumbuh tanaman yang berperan dalam proses pembelahan dan pemanjangan sel. Dengan demikian, maka pertumbuhan tanaman akan menjadi optimal.

\section{KESIMPULAN}

Kesimpulan dari penelitian ini adalah PGPR dapat memacu pertumbuhan tanaman kentang hitam pada proses pembibitan tanaman kentang hitam. Namun, dosis $25 \%$, $50 \%, 75 \%$, dan $100 \%$ tidak menunjukkan perbedaan respon pertumbuhan yang signifikan pada tanaman kentang hitam.

\section{UCAPAN TERIMA KASIH}

Terimakasih kepada Direktorat Jenderal Pembelajaran dan Kemahasiswaan Kementrian Riset, Teknologi, dan Pendidikan Tinggi yang telah mendanai penelitian ini.

\section{DAFTAR PUSTAKA}

Anonim. (2012). Fungsi hormon auksin, Sitokinin, Giberelin, Asam Absisat. https ://rumahhujau.wordpress.com. Diakses 1 September 2018.

Fitriani, A. (2017). Respon Pertumbuhan Tanaman. (online) (http://repository.ump.ac.id) diakses tanggal, 05 januari 2019. 


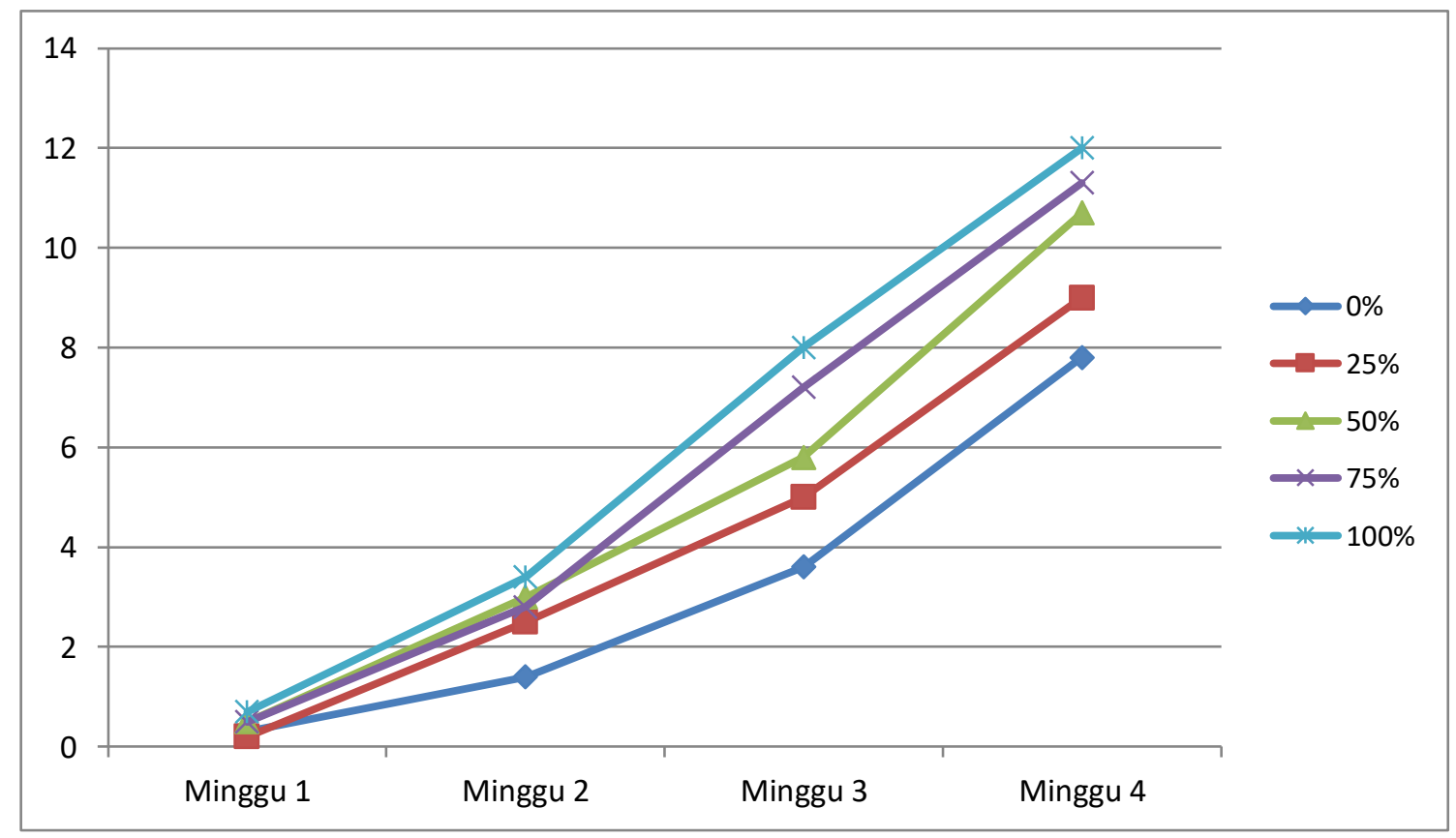

Gambar 1. Tinggi Tanaman Kentang Hitam (S. rotundifolius) selama 4 MST

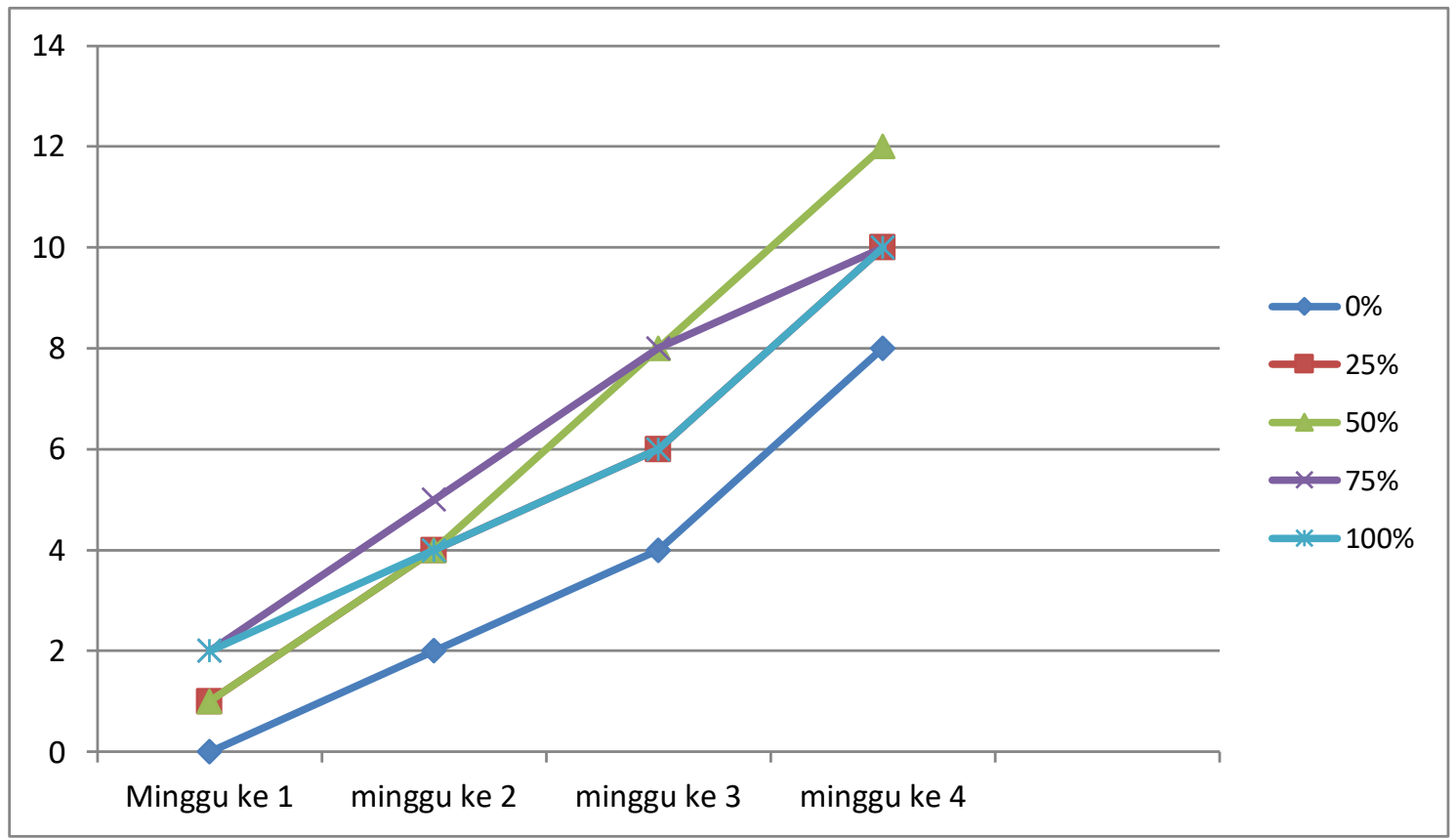

Gambar 2. Jumlah DaunTanaman Kentang Hitam (S. rotundifolius) selama 4 MST

Gupta, G., Parihar S. S., Ahirwar NK., Snehi SK., Singh V. (2015). Plant Growth Promoting Rhizobacteria (PGPR): Current and Future Prospect for Development of Sustainable Agriculture. J Microb Biochem Technol 7: 096-102. http://doi:10.4172/1948-5948.1000188.
Kurniahu, H., Sriwulan, \& Andriani, R. (2017). Aplikasi PGPR Rizhosfer Gramineae Terhadap Pertumbuhan Jahe Merah (Zingiber officinale Var.Rubrum). jurnal pena sains Vol. 4, No. 2

Maulina, N.M.I., Khalimi, K., Wirya, G.N.A.S., \& Suprapta, D.N. (2015). Potensi Rizobakteri yang Diisolasi dari Rizosfir Tanaman Graminae Non-Padi untuk 
Memacu Pertumbuhan Bibit Padi. Agric. Sci. and Biotechnol. Vol 4 (1).

Nugraheni, M., Hamidah, S., \& Auliana, R. (2016). Pengaruh Konsumsi Crackers Kentang Hitam (Coleus tuberosus) Kaya Resistant Starch tipe 3
Terhadap Profil Lipida yang Menderita Hiperkolesterolemia. Jurnal penelitian saintek Vol. 21, No.1

Putro, A.T.A.M. (2010). Budidaya Tanaman Kentang (Solanum tuberosum, L) Diluar Musim Tanam. 